\title{
PAIKEM: Fun Learning as a Strategy to Improve Learning Achievement of High School Students in South Aceh
}

\author{
Muhammad Jafar' ${ }^{1}$, RN Herman ${ }^{2}$, Rahmad Nuthihar ${ }^{3}$, M Chairul Basrun Umanailo ${ }^{4}$ \\ ${ }^{1,2}$ Universitas Syiah Kuala, Banda Aceh, Indonesia \\ ${ }^{3}$ Akademi Komunitas Negeri Aceh Barat \\ ${ }^{4}$ Universitas Iqra Buru \\ 1jafar.m1968@gmail.com
}

\begin{abstract}
This research is related to the role of teachers in the application of active, innovative, creative, effective, and fun learning (PAIKEM) to improve the learning achievement of high school students in South Aceh District. This research uses a quantitative approach with descriptive research type. The population of this study were students of class XI high school in South Aceh District for the academic year 2019/2020. There are 1376 students who are the population of this study. Given the large population, this study uses Cluster Sampling and Proposional Random Sampling to determine the research sample. The sample of this research is 176 students of class XI high school in South Aceh District. Data collection techniques were carried out through questionnaires and documentation. The data analysis technique uses a percentage in order to know the answer to each item and the product moment correlation formula to determine the level of the relationship between learning achievement and learning methods. The results showed that the role of teachers in implementing PAIKEM in South Aceh District was running well with a percentage of $38 \%$. There is a positive and significant relationship between the role of teachers in the application of PAIKEM and student achievement $(r=0.203)$ so that the application of PAIKEM contributes $20 \%$. It is hoped that teachers will always take the initiative in developing their expertise in implementing learning in accordance with PAIKEM so that the teaching and learning process is more enjoyable and can improve student learning achievement
\end{abstract}

Keywords

PAIKEM, fun learning, active learning, learning achievement

Article Received: 10 August 2020, Revised: 25 October 2020, Accepted: 18 November 2020

\section{Introduction}

Education is a human need in life. Qualitative growth and development of a person is also the result of the educational process, whether consciously or not. In simple terms, education intends to develop all the potential that an individual naturally has. The potential that exists in this individual will become a hidden resource without seeing and feeling the results if it is not developed effectively and creatively.

Jamaliah, (2019) said that education that is able to build the future of students is education that is able to develop the potential of students. Every teacher must be able to apply active and creative learning so that students enjoy participating in the teaching and learning process. Students are also required to be able to overcome various problems in everyday life with the learning methods they have obtained. Therefore, appropriate learning methods and strategies are needed to help develop the potential of students.

There are many learning methods and models that require students to be active, creative, and innovative. The teacher as a facilitator is expected to master the right model for the appropriate material so that student learning achievement increases and student learning motivation also increases (Arisetiyana et al., 2020). This is in line with the goals of education to develop and direct students to become human figures who have the main and perfect personality (Slameto, 2003). With a good education, humans can develop personalities, both physical and spiritual, for a better direction in their lives. For this reason, various strategies must be owned and tested by educators in order to see which strategies or models can develop students' creativity and motivation in learning. This is in line with Law of the Republic of Indonesia number 20 of 2003 concerning the National Education System. Chapter I states that "Education is a conscious and planned effort to create an atmosphere of learning and the learning process so that students actively develop their potential to have religious spiritual strength, self-control, personality, intelligence, noble character, and skills needed by themselves, society, nation and state".

Education that is able to increase the learning motivation of students is education that has a positive influence on student learning outcomes. Learning achievement is the main measure to determine a person's learning success. A person with high achievement can be said that he has succeeded in learning (Slameto, 2003). Therefore, in many schools, the teaching and learning process approach is emphasized to increase learning motivation as well as learning achievement (Alexopoulos, 2020). It must be admitted that among the determining factors whether or not students succeed in the teaching and learning process is the learning method. Apart from students, the most important element in learning activities is the teacher. Teachers as teachers who provide knowledge as well as educators who teach values, morals, morals and socially and to carry out this role are required to have broad knowledge and insight, which will later be taught to students so that they can improve student learning achievement. Student learning achievement can be achieved by learning activities that are liked and liked by students. Therefore, teachers are required to have a strategy in developing an active, creative, innovative, and fun learning process. In Indonesia, this learning process is called 
PAIKEM. In the world, this active and fun learning process is known as physical active learning or PAL (Daly-Smith et al., 2020). Apart from motivating students' enthusiasm for learning, this method also directs students to think critically. This is a challenge for every teacher because developing critical thinking skills in every student is not an easy job (Oltievna \& Aktamovna, 2020).

The National Education Standards Agency (BSNP) states that sports and health physical education aims to make students able to improve basic mobility skills and abilities. With adequate basic movements, it is expected to be able to motivate student learning in an active, creative, and fun way. This confirms that improving the application of PAIKEM is related to the agility of students in moving their bodies.

The PAIKEM learning method is a competency-based learning process. This method is intended to create a fun teaching and learning process in order to achieve satisfactory learning achievement. Thus, the application of PAIKEM will be maximized if teachers master various games as an active and fun learning strategy, because fun learning is learning that is integrated with several forms of play (Khairani et al., 2020). Several games developed in the application of PAIKEM will help create a learning process that demands student activity while creating a pleasant atmosphere. This method also provides relief to the teacher because the method of learning while playing requires children to be active, giving the teacher the opportunity to simply act as a facilitator (Putranto et al., 2019).

In PAIKEM learning, the teacher must create a comfortable and pleasant atmosphere so that students actively ask, question, and express ideas. The Physical Education subject is one of the subjects that fully supports the PAIKEM teaching and learning process. This subject requires movement, patience, accuracy, thoroughness, discipline, and pleasant situations. For this reason, teachers are required not only to be able to deliver material orally or lecture, but also to be able to practice learning activities conveyed to students, all of which cannot be separated from their pleasant nature.

Teachers who are active, innovative, creative, and professional are required to have the ability to develop approaches and choose effective learning models. This is especially important to create a pleasant learning climate. Teachers need a different approach and strategy from other learning because basically the Physical Education subject is very different from other subjects. (Bartholomew et al., 2019) have conducted research on the application of active learning. However, Bartholomew's research looks more at the gender side. This study does not look at student achievement in terms of gender, but from the application of active, innovative, creative, effective, and fun learning by the teacher. This research is focused on high school teachers throughout South Aceh. This is because South Aceh is a coastal area. Students who study in South Aceh are generally children of fishermen and farmers who daily help their parents to the sea and mountains. According to (Eryiğit \& Ay, 2021), learning achievement is also related to the activity background of students. Thus, it is important to see the learning achievement of students who are generally children of fishermen and farmers regarding fun learning methods.
Several studies that are relevant to this research include The Effectiveness of Cooperative learning approach on Arabic Teaching among Non-Native Speakers at Universities in Malaysia (Mei et al., 2020); Motivation And Student Learning Outcomes In Problem Based Learning (Arisetiyana et al., 2020); Development of a Multilateral Motion Learning Model Based on Role Playing Game (RPG) for Elementary School Students (Putranto et al., 2019); Active Learning Increases Children's Physical Activity across Demographic Subgroups (Bartholomew et al., 2019). In addition, (Silvestre-López, 2020) conducted a study on the motivation of students with disabilities towards active learning for sports subjects. Therefore, research on the application of PAIKEM to student achievement is important.

\section{Methodology}

This research includes educational research with a quantitative approach. This type of research is classroom action research. The method used in this research is descriptive method with a survey approach. (Sugiyono, 2013) states that quantitative research is related to positivism philosophy, which is examining samples in certain populations. The sampling technique was carried out randomly on a population of 1376 students in order to obtain a sample of 176 people. All of these students are representatives of high school in South Aceh District, Aceh Province, Indonesia.

\section{Results}

This study first looked at several high schools in South Aceh District that had teachers. The teachers were observed first to find out which teachers applied PAIKEM in the teaching and learning process. The next step is to see the level of their PAIKEM application in the classroom so that the research sample is recorded.

From the table above, it can be seen that high school teachers in South Aceh have maximally implemented PAIKEM in the teaching and learning process. The level of PAIKEM application for the teachers reached 14802. Thus, the average PAIKEM application scores in high schools of South Aceh are as follows.

$M X=\frac{\sum X}{N}=\frac{14802}{176}=84.10$

Explanation:

$\mathrm{MX}=$ Median

$\sum \mathrm{X}=\quad$ The total of PAIKEM application scores

$\mathrm{N}=$ Number of Samples

Next, the total student achievement results amounted to 14250. To obtain the average score for student learning outcomes, it can be seen through the following formula. Next, the total student achievement results amounted to 14250. To obtain the average score for student learning outcomes, it can be seen through the following formula.

$M X=\frac{\sum Y}{N}=\frac{15377}{176}=87.36$ 
Explanation:

$$
\begin{aligned}
\mathrm{MX} & =\text { Median } \\
\sum_{\mathrm{Y}} & =\text { Total value of learning achievement } \\
\mathrm{N} & =\text { Number of Samples }
\end{aligned}
$$

If we look at the results of implementing PAIKEM in high schools in South Aceh, how many results are above enough. This shows that the application of active, creative, innovative, effective, and fun learning in high school in South Aceh has been running optimally. The average score for implementing PAIKEM in this district stands at 84.10. The results of students' learning also looked very satisfying with an average score of 87.36 for their learning achievement.

Based on this average value, it can be seen that the conditions for implementing PAIKEM and the learning achievement scores of the public high school students in South Aceh District are already in very good stages. The application of PAIKEM with excellent learning outcomes can be an example for other schools that PAIKEM can improve student achievement. Note the relationship between the application of PAIKEM and the learning achievement in class XI students of Senior High Schools in South Aceh District below.

The table above shows the values of the relationship between PAIKEM implementation and physical education achievement in hihgh school in Aceh Selatan District are very significant. The relationship between PAIKEM application and student achievement can be calculated using the following formula.

$r_{X Y}=\frac{N \sum X Y-\left(\sum X\right)\left(\sum Y\right)}{\sqrt{\left\{N \sum X^{2}-\left(\sum X\right)^{2}\right\}\left\{N \sum Y^{2}-\left(\sum Y\right)^{2}\right\}}}$

Where:

$\mathrm{N}=176, \quad \sum \mathrm{X}=14802, \quad \sum \mathrm{Y}=15377, \quad \sum \mathrm{XY}=1294117$ $\sum \mathrm{X}^{2}=1255534$,

$\sum Y^{2}=1345219$

Then:

$r_{X Y}=\frac{176 \times 1294117-(14802)(15377)}{\sqrt{\left\{176 \times 1255534-(14802)^{2}\right\}\left\{176 \times 1345219-(15377)^{2}\right\}}}$
$r_{X Y}=\frac{227764592-227610354}{\sqrt{\{220973984-219099204\}\{236758544-236452129\}}}$
$r_{X Y}=\frac{154238}{\sqrt{1874780 \times 306415}}$
$r_{X Y}=\frac{154238}{\sqrt{574460713700}}$
$r_{X Y}=\frac{154238}{757931.866}$
$r_{X Y}=0,203$

The calculation result above shows that the correlation coefficient is 0.203 . This value needs to be tested for its significance by consulting the $\mathrm{r}$ table. The value of $\mathrm{r}$ table in degrees of freedom $(\mathrm{db})=\mathrm{N}=176$, for an error of $5 \%=$ 0.159 (Table $r$ values are listed in the appendix). It turns out that $\mathrm{t}$ is greater than $\mathrm{r}$ table, namely $0.203>0.159$. Then the correlation coefficient 0.203 is significant and related.

It can be concluded that there is a positive and significant relationship between the role of teachers in the implementation of PAIKEM and the learning achievement in high school students in South Aceh District.

To test the research hypothesis, a guideline for interpreting the correlation coefficient with the t-test can be used. The test criteria are $\mathrm{Ha}$ is accepted if $\mathrm{t}$-count $>$ from $\mathrm{t}$-table, and $\mathrm{Ha}$ is rejected if $\mathrm{t}$-count $<$ from t-table with a significant level of $5 \%$ where the $t$ distribution used has $\mathrm{dk}=\mathrm{n}-2$, the test can be seen as following.

$$
t=\frac{r \sqrt{n-2}}{\sqrt{1-r^{2}}}
$$

Where:

$\mathrm{n}=176, \mathrm{r}=0.203$.

Then:

$$
\begin{aligned}
& t=\frac{0,203 \sqrt{176-2}}{\sqrt{1-0.203^{2}}} \\
& t=\frac{0,203 \sqrt{174}}{\sqrt{1-0,041}} \\
& t=\frac{0,203 \times 13,190}{\sqrt{0,959}} \\
& t=\frac{2,67757}{0,97928} \\
& t=2,73
\end{aligned}
$$

The calculation result shows that the t-count value is 2.73 , while the t-table value is 1.98 (listed in the attachment). Based on the test criteria, it can be concluded that the tcount $>$ from the t-table is $2.73>1.98$. It can be concluded that by proving a significant level of $5 \%$, the study accepts Ha, namely: there is a relationship between the role of teachers on the implementation of PAIKEM and the learning achievement High School South Aceh District.

\section{Conclusion}

Based on the results of the research, it is known that the application of active, innovative, creative, effective, and fun learning (PAIKEM) in High Schools in South Aceh District has been going very well. The relationship between the role of teachers in High School in South Aceh District on the implementation of PAIKEM with learning achievement in sports and health physical education is used to analyze the produc moment correlation. From the calculation, the correlation coefficient is 0.203 .

The results of this study indicate that the application of learning methods is very influential on student achievement. As suggested by (Slameto, 2003) that a teacher in delivering material needs to choose which method is appropriate to the situation of the class or students so that students feel interested in following the lessons being taught. With a variety of methods can improve learning activities and student achievement.

It can be concluded that the $\mathrm{t}$-count is $2.73>$ from the $\mathrm{t}$-table 1.98. This proves that with a significant level of $5 \%$ of the study accepts $\mathrm{Ha}$ and rejects Ho, namely "There is a relationship between the role of physical education teachers on the implementation of PAIKEM and the learning achievement of physical education and physical education in High School in South Aceh District". Thus, the role of 
teachers in the application of active, innovative, creative, effective and fun learning (PAIKEM) in High Schools in South Aceh District has been running quite well.

From the results of the study it can also be concluded that there is a positive and significant relationship between the role of teachers in the implementation of PAIKEM and the learning achievement of High School students in South Aceh District $(r=0.203)$ so that the implementation of PAIKEM contributes 20\%. Thus, teachers in High Schools in South Aceh District are expected to always take the initiative to develop their abilities and expertise in implementing learning in accordance with PAIKEM, especially in active and creative learning indicators. Students are expected to participate actively and diligently in following the learning process in order to gain more knowledge and understanding. The school is expected to create a more complete learning environment and learning facilities so that it can help the smooth and active learning process.

\section{References}

[1] Alexopoulos, P. (2020). Participation Motivation Among Young Soccer Athletes: Research Evidence From Greece. European Journal of Physical Education and Sport Science, 6, 49-59. https://doi.org/10.46827/ejpe.v6i7.3325

[2] Arisetiyana, F. F., Dwi Cahyo Kartiko, Nanik Indahwati, \& Bayu Budi Prakoso. (2020). Motivation And Student Learning Outcomes In Problem Based Learning. Jurnal Pendidikan Jasmani, Olahraga Dan Kesehatan, 4(30), 1-10.

[3] Bartholomew, J. B., Esbelle M. Jowers, Gregory Roberts, Anna-Mária Fall, Vanessa, \& Vaughn, L. E. S. (2019). Active Learning Increases Children's Physical Activity across Demographic Subgroups. Physiology \& Behavior, 176(3), 139-148. https://doi.org/10.1249/TJX.00000000000 00051.Active

[4] Daly-Smith, A., Quarmby, T., Archbold, V. S. J., Routen, A. C., Morris, J. L., Gammon, C., Bartholomew, J. B., Resaland, G. K., Llewellyn, B., Allman, R., \& Dorling, H. (2020). Implementing physically active learning: Future directions for research, policy, and practice. Journal of Sport and Health Science, 9(1), 41-49. https://doi.org/10.1016/j.jshs.2019.05.007
[5] Eryiğit, Ö., \& Ay, S. M. (2021). An Investigation of Physical Activity Levels of Academicians in Sport Science. European Journal of Physical Education and Sport Science, 6(10), 1-12. https://doi.org/10.46827/ejpe.v6i10.3497

[6] Jamaliah, N. (2019). Peningkatan Hasil Belajar Passing Bawah Bola Voli Melalui Torgamba Kabupaten Labuhan Batu Selatan Model Pbbt Dan Pbkl Siswa Kelas Viii Smpn 1. Universitas Islam Kalimantan Muhammad Arsyad AlBanjari Banjarmasin, 1-8.

[7] Khairani, M. Z., Ibrahim, N., Ladin, C. A., \& Arif, H. A. (2020). Integration Of Theatre Game Approach In Visual Art Education At The Secondary School Setting . Psychology And Education, 57, 193-205.

[8] Mei, S. Y., Zakaria, M., Ju, S. Y., \& Ibrahim, M. (2020). The Effectiveness of Cooperative learning approach on Arabic Teaching among Non- Native Speakers at Universities in Malaysia. PSYCHOLOGY AND EDUCATION, 57, 272-279.

[9] Oltievna, K. F., \& Aktamovna, A. D. (2020). The Actuality And The Content Of Forming Critical Thinking Skills Of Primary School Pupils. PSYCHOLOGY AND EDUCATION, 57, 555-563.

[10] Putranto, D., Ulfah, W. A., Muhammadiyah, S., \& Belitung, B. (2019). Pengembangan Model Pembelajaran Gerak Multilateral Berbasis Role Playing Game (Rpg) Pada Siswa Sekolah Dasar. Universitas Islam Kalimantan Muhammad Arsyad AlBanjari Banjarmasin, 17-25.

[11] Silvestre-López, A. J. (2020). Conceptual metaphor in meditation discourse: An analysis of the spiritual perspective. GEMA Online Journal of Language Studies, 20(1), 35-53. https://doi.org/10.17576/gema-2020-200103

[12] Slameto. (2003). Belajar dan Faktor-faktor yang Mempengaruhinya. Rineka Cipta. 
[13] Sugiyono. (2013). Metode Penelitian Kuantitatif Kualitatif dan R\&D. Penerbit Alfabeta. 